\title{
Surface Modification of Biomaterials for Conjugation with Human Fetal Osteoblasts
}

\author{
Françoise Borcard\$̊a, Phally Kong ${ }^{a}$, Céline Journota ${ }^{a}$ Davide Staedler ${ }^{a}$, Philip N. Sturzenegger ${ }^{b}$, \\ Franziska Krauss Juillerat ${ }^{b}$, Urs T. Gonzenbach ${ }^{b}$, Lucienne Juillerat-Jeanneret ${ }^{c}$, and Sandrine \\ Gerber-Lemaire $^{\star_{a}}$
}

§SCS-Metrohm Foundation Award for best oral presentation

\begin{abstract}
Surface functionalization of hydroxyapatite $(\mathrm{HA})$ and $\beta$-tricalcium phosphate (TCP) bioceramics with chemical ligands containing a pyrrogallol moiety was developed to improve the adhesion of bone cell precursors to the biomaterials. Fast and biocompatible copper-free click reaction with azido-modified human fetal osteoblasts resulted in improved cell binding to both HA and TCP bioceramics, opening the way for using this methodology in the preparation of cell-engineered bone implants.
\end{abstract}

Keywords: Cell adhesions · Copper-free click reaction · Functionalized biomaterials · Human fetal osteoblasts

\section{Introduction}

Over the last decade, bone-related diseases such as osteogenesis imperfecta, osteoarthritis, osteomyelitis, and osteoporosis, traumatic injuries and orthopedic surgeries have dramatically increased. The reasons for this drastic development can be found in the ageing of the population and the democratization of high-risk sports. ${ }^{[1]}$ The current gold standard to treat large bone defects is still autologous iliac crest graft. ${ }^{[2]}$ Another option for patients and surgeons is the use of allograft-based bone tissue from other humans and in most cases from cadavers. Many orthopedic allograft procedures have been approved by the FDA and applied for years in hospitals. Success in both allografts and autografts results from the physical and biological similarity between the donor and host tissue. ${ }^{[3]}$ Nevertheless, the need for a second

\footnotetext{
${ }^{*}$ Correspondence: Dr. S. Gerber-Lemaire ${ }^{a}$ Tel.: +41216939372 E-mail: Sandrine.Gerber@epfl.ch alnstitute of Chemical Sciences and Engineering EPFL, CH-1015 Lausanne ${ }^{b}$ Nonmetallic Inorganic Materials ETHZ, CH-8093 Zürich

'University Institute of Pathology CHUV-UNIL, $\mathrm{CH}-1011$ Lausanne
}

surgery with its increased risk of infection, pain, donor site morbidity, disease transmission and rejection (in the case of allografts), as well as monetary aspects call for the development of synthetic bone graft materials which today are used in only $15 \%$ of cases. ${ }^{[1]}$ Recent advances in the understanding of the chemical and biological processes of bone tissue regeneration have led to a new generation of synthetic bone substitute materials that show good potential for the treatment of large bone defects.

One of the biggest challenges in bone tissue engineering is the complete colonization of the graft biomaterial by osteoblasts, especially in the inner area of implants. Due to the lower availability of nutrients and oxygen, the cells present in the inner area migrate to the surface. To overcome this problem we propose to establish a covalent linkage between implant materials and human fetal osteoblasts (FsOs) allowing a better colonization of the scaffold. These cells have an interesting potential for therapeutic use in bone tissue engineering, due to their rapid growth rate, their ability to differentiate in vitro into mature osteoblasts and their histocompatibility. ${ }^{[4,5]}$

During the last decade, the development of bioorthogonal ligation has improved the possibility to study cellular processes. ${ }^{[6]}$ Among the chemical motifs developed for these reactions, azide appears as one of the most versatile bioorthogonal reporters due to its stability under physiological conditions and its small size that has generally only minimal effects on the structure of the tagged molecules. ${ }^{[7]}$ Azides can react through
Staudinger ligation with triarylphosphines and dipolar cycloadditions to alkynes, under mild reaction conditions. ${ }^{[8,9]}$ In this study, copper-free $[3+2]$ dipolar cycloaddition (click reaction) ${ }^{[10]}$ was investigated to form a covalent linkage between modified FsOs and biomaterials. ${ }^{[11]}$ We disclose herein the synthesis of a chemical ligand containing an activated alkyne for the copper-free click reaction and its ligation to azido-modified FsOs. The cytotoxicity of this reaction for the cells was also evaluated for several days. We also determined whether the adhesion of FsOs to bioceramics of different compositions - hydroxyapatite (HA) and $\beta$-tricalcium phosphate (TCP) - can be improved by chemical functionalization of the scaffold with a specific ligand allowing the copperfree click reaction with FsOs. ${ }^{[12]}$

\section{Results}

\section{Synthesis of the Chemical Ligand for the Copper-free Click Reaction}

The synthesis of activated cyclooctyne, DIBO, was performed according to the published data. ${ }^{[13]}$ After activation with 4-nitrophenyl chloroformate to give carbonate $\mathbf{2}$, the resulting intermediate was treated with derivative $\mathbf{3}$ containing a tetraethyleneglycol chain required for higher solubility in biological medium and a biotin label for the detection with a fluorescent streptavidin to afford the model ligand 4 used for further evaluation of the copperfree click reaction on azido-modified FsOs (Scheme 1). 


\section{Synthesis of the Chemical Ligand for the Copper-free Click Reaction on Biomaterials}

3,4,5-Triacetoxy benzoic acid (5) was first converted into the corresponding acyl chloride by reaction with oxalylchloride in the presence of DMF and then coupled to N-Boc-1,6- hexanediamine to afford intermediate 6. After cleavage of the carbamate under acidic conditions, the resulting amine 7 reacted with activated DIBO 2 in the presence of triethylamine. Deprotection of the three hydroxyl groups under basic conditions provided the desired compound $\mathbf{8}$ which was further used for the functionalization of the biomaterial and the click reaction with FsOs (Scheme 2).

\section{Copper-free Click Reaction with FsOs}

Compound 4 presenting activated cyclooctyne can react with azide moieties without copper catalyst since the loss of the ring strain $(18 \mathrm{kcal} / \mathrm{mol})$ and the additional strain imposed by two aromatic rings decrease the activation energy of the click reaction. In order to express azidomodified proteins, human fetal osteoblasts were cultured in the presence of the nonnatural amino acid L-azidohomoalanine (AHA) to insert an azide moiety in cellular proteins, without cell alterations. ${ }^{[8]}$ Copper-free click reaction of compound 4 (Fig. 1A-D) with azido-modified FsOs was performed at room temperature for $1 \mathrm{~h}$ in culture medium without FCS, containing additional HEPES $(20 \mu \mathrm{M})$ for buffering. Cell nuclei were labeled with DAPI and the cell functionalization was monitored by fluorescence microscopy using Cy3-streptavidin. In the absence of preincubation of cells with AHA no labeling was detected. Ligand $\mathbf{4}$, containing an activated alkyne moiety, allowed fast click reactions with azido-modified FsOs at the concentration of 20,50 and $100 \mu \mathrm{M}$ in the incubation medium (Fig. 1).

\section{Evaluation of the Cytotoxicity of the Copper-free Click Reaction on FsOs}

The biocompatibility of this reaction was evaluated by monitoring the cell viability using the WST-1 assay of functionalized FsOs for up to $144 \mathrm{~h}$ after the chemical reaction (Fig. 2). No cytotoxicity on FsOs was observed for the copper-free click reaction. This technique can thus be further applied to long-term cellularization of implant biomaterials.

\section{Click Reaction on HA and TCP Biomaterials}

After having proved that copper-free click reaction can be used as an efficient tool for the functionalization of FsOs surface, we further investigated this reaction

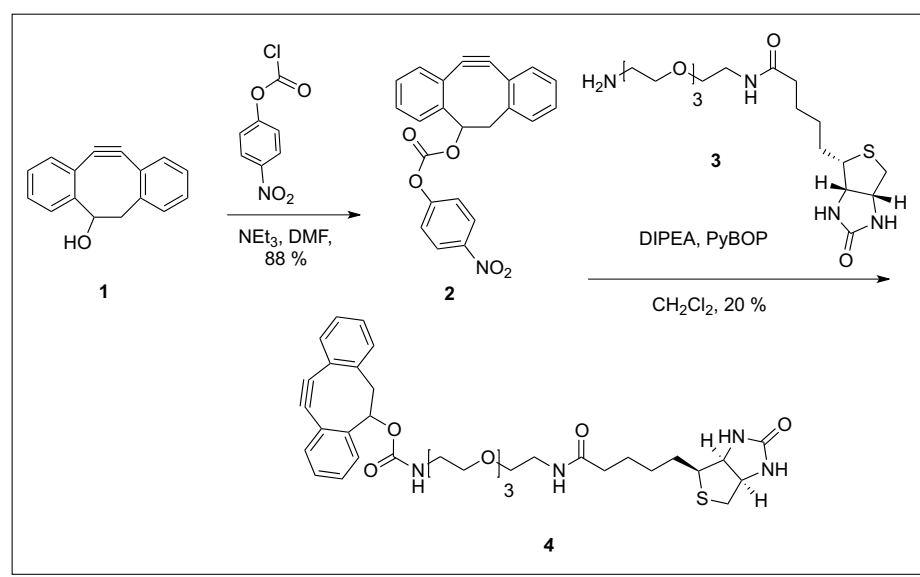

Scheme 1. Synthesis of the model linker for the copper-free click reaction on FsOs.

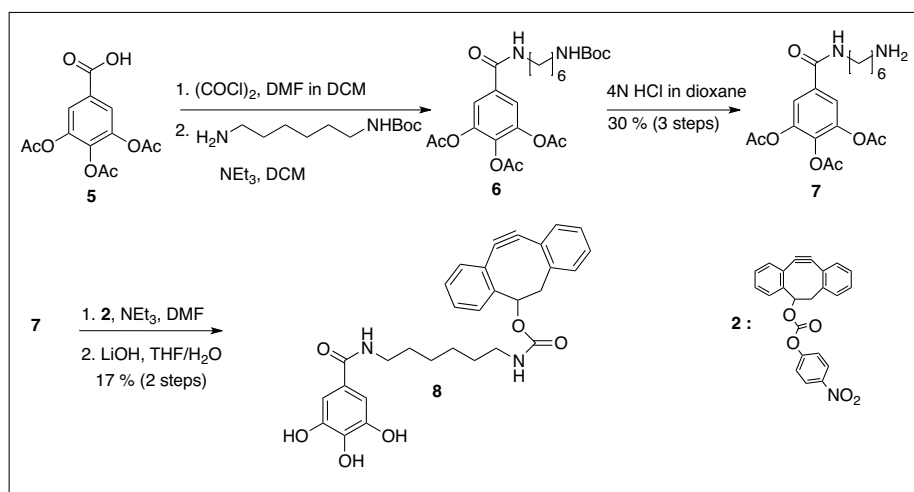

Scheme 2. Synthesis of the ligand for the copper-free click reaction on biomaterials.
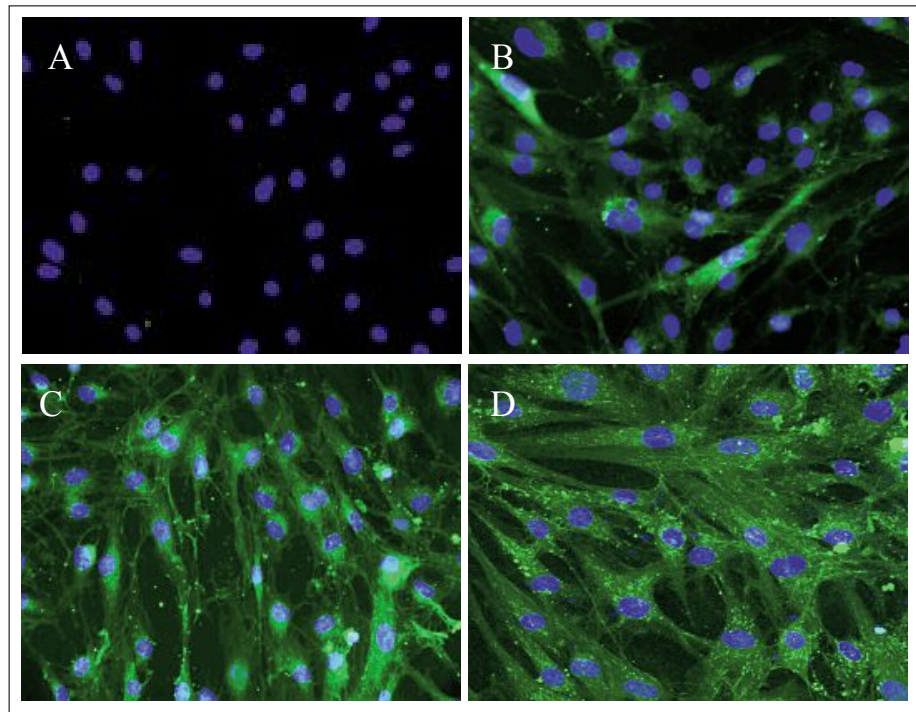

Fig. 1. Copper-free click reactions performed on FsOs. (A) To evaluate the non-specific binding, FsOs without preincubation with AHA were exposed to biotin-containing compound 4, then to fluorescent Cy3streptavidin to label biotin and DAPI to label cell nuclei. (B-D) FsOs were preincubated with AHA and subsequently exposed to compound 4 (20, $50,100 \mu \mathrm{M})$ for $1 \mathrm{~h}$ at $25^{\circ} \mathrm{C}$ using copper-free click reaction, then to fluorescent streptavidin to label biotin and to DAPI to label cell nuclei.

with ligands conjugated to biomaterials of different chemical compositions. For that purpose, the ligand $\mathbf{8}$ combining a pyrrogallol moiety for attachment to the inorganic matrix of the biomaterial ${ }^{[14]}$ and DIBO was used. The hydroxyapatite (HA) and $\beta$-tricalcium phosphate (TCP) biomaterials were functionalized by incubation with a 0,5 or $10 \mu \mathrm{M}$ solution of 8 for $24 \mathrm{~h}$.
Then the azido-labeled FsOs $\left(10^{5}\right.$ cells per disc of biomaterial) were added to biomaterial discs which were either unfunctionalized or had been pre-functionalized with compound $\mathbf{8}$. After the washing and fixation steps, the cells were stained with crystal violet. Cell adhesion to the biomaterials was imaged with a stereomicroscope and the number of adhered cells was quantified 


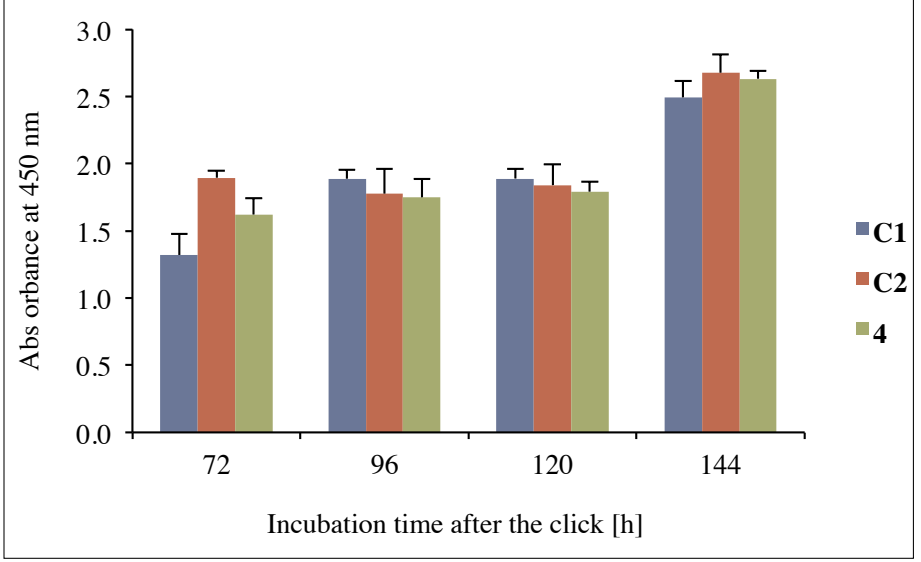

Fig. 2. FsOs were pre-incubated overnight with $\mathrm{AHA}(\mathbf{C 2}$ or $\mathbf{4})$ or with vehicle as control (C1), then the copper-free click reaction was performed for $1 \mathrm{~h}$ at $25^{\circ} \mathrm{C} \mathrm{(4)}$ or cells were incubated in complete medium for $1 \mathrm{~h}$ at $25^{\circ} \mathrm{C}$ as control (C1 and C2). Cells were further incubated for $72 \mathrm{~h}$ to 144 $\mathrm{h}$, and then the WST-1 assay was performed. Results are the means \pm sd of triplicate wells of a representative experiment out of three independent experiments.

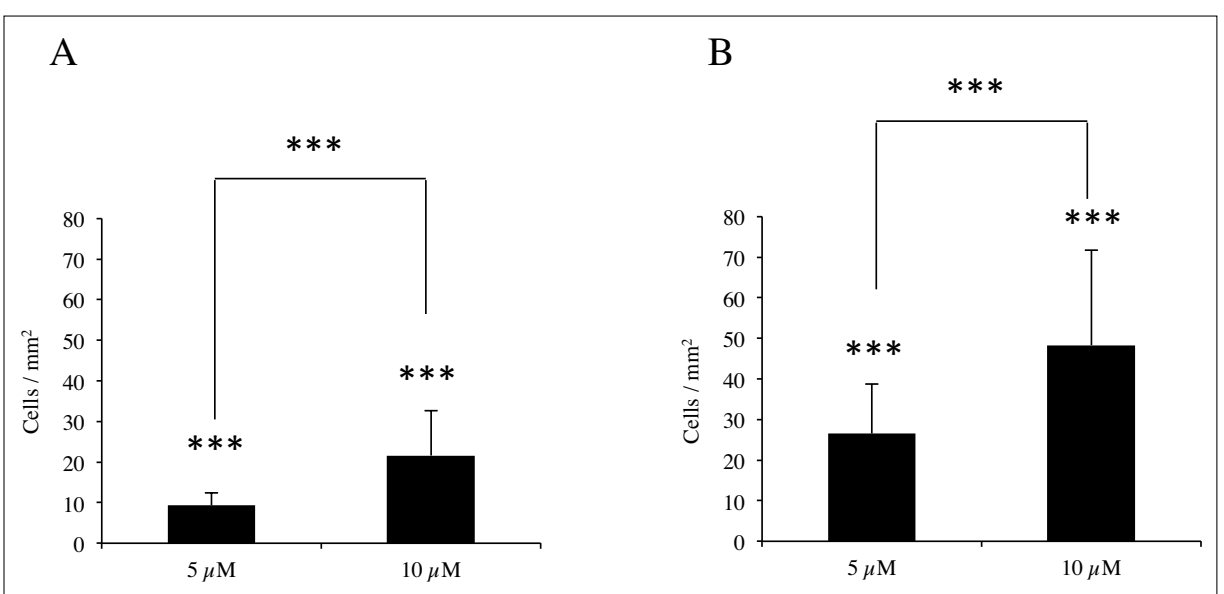

Fig. 3. The quantification of the number of cells adhered to the discs of bioceramics was performed by analysis of stereomicroscopy pictures. A: HA and B: TCP. The number of cells bound to the bioceramic discs was compared between unfunctionalized scaffolds $(0 \mu \mathrm{M})$ and scaffolds functionalized with compound $8(5 \mu \mathrm{M}$ or $10 \mu \mathrm{M})$ using a Student's $t$-test : ${ }^{\star \star \star}: \mathrm{p}<0.001$. The correlation coefficient $\left(\mathrm{R}^{2}\right)$ was calculated between the number of adhered cells on scaffolds functionalized with $5 \mu \mathrm{M}$ and $10 \mu \mathrm{M}$ of compound $8 . \mathrm{R}^{2}=1.00$. Results are the mean $\pm \mathrm{sd}$ of triplicates of three independent experiments.

by the IMAGE J software for each material (Fig. 3). Quantification of the number of bound cells to the discs of biomaterials showed that the functionalization of the discs with compound $\mathbf{8}$ significantly ( $p$ $<0.001$ ) increased the number of adhered cells, with a very strong dependency (10 $\mu \mathrm{M}$ vs $5 \mu \mathrm{M}$ : $\mathrm{p}<0.001$, correlation $=1$ ) on the concentration of compound $\mathbf{8}$ used for the functionalization of the two types of biomaterials. No cells were bound on the unfunctionalized discs of bioceramics. TCP biomaterial showed a higher number of bound cells compared to HA.

\section{Discussion}

The colonization of the inner surface of bone substitute materials by osteoblasts has to be reached to ensure homogeneous bone reconstruction and success of the implant. In this study, copper-free click reaction on human fetal osteoblasts was first evaluated to determine if a chemical compound can be bound to the cell surface without any cytotoxicity. After the synthesis of a model ligand 4 containing an activated alkyne, a polyethylene chain and a biotin moiety, the copper-free click reaction was performed with this compound on modified FsOs and monitored by fluorescence microscopy using a fluorescent streptavidin. Cell surface modification was only observed on FsOs pre-incubated with the non-natural amino acid AHA. A 50 to $100 \mu \mathrm{M}$ concentration of ligand 4 was optimal to achieve a high rate of functionalization. Then the viability of functionalized FsOs was evaluated for up to 144 hours after the click reaction. No decrease of the cell survival was observed compared to the non-functionalized cells, suggesting that this modification is not toxic for FsOs.

A second chemical ligand $\mathbf{8}$ containing a pyrrogallol moiety for the binding to the biomaterial discs ${ }^{[14]}$ and a cyclic activated alkyne for the covalent linkage to FsOs was synthesized in reasonable yield. The HA and TCP biomaterials were then functionalized at different concentrations with ligand $\mathbf{8}$ and AHA-labeled FsOs were added. A significantly higher number of adhered FsOs was observed on the functionalized biomaterials and was strongly correlated with the concentration of ligand 8 used for surface modification of the biomaterials. Better results were obtained for TCP bioceramic than HA bioceramic, the number of adhered cells being higher with this material. This observation was in accordance with previous results obtained for other functionalizing ligands. [15]

In conclusion, surface functionalization of HA and TCP biomaterials provides an efficient tool to promote the adhesion of bone precursor cells to the scaffolds using the copper free click reaction. The biocompatibility of this chemical transformation opens the way to further development of functionalized bioceramics as cell-engineered bone implant materials.

\section{Experimental Section}

\section{Chemical Syntheses}

Commercial reagents (Fluka, Aldrich, VWR, Switzerland) were used without further purification. Anhydrous solvents were obtained by filtration (PureSolv MD Series, Innovative Technology). TLCs for reaction monitoring were performed on Merck silica gel 60 F254 plates, and spots were revealed with UV light and reaction with $\mathrm{KMnO} 4$ or ninhydrine. IR spectra were recorded on a Perkin-Elmer-1420 spectrometer. ${ }^{1} \mathrm{H}-\mathrm{NMR}$ spectra were recorded on a Bruker ARX-400 spectrometer (400 $\mathrm{MHz}$ ) using $\mathrm{CDCl}_{3}$ or $\mathrm{MeOD}$ as solvent and calibrated using the solvent's residual signal at 7.27 or $3.31 \mathrm{ppm}$ as an internal reference. ${ }^{13} \mathrm{C}$-NMR spectra were recorded on a Bruker ARX-400 spectrometer (100.6 $\mathrm{MHz}$ ) using $\mathrm{CDCl}_{3}$ or $\mathrm{MeOD}$ as solvent and calibrated using the solvent's residual signal at 77.0 or $49.0 \mathrm{ppm}$ as an internal reference. Chemical shifts are expressed in parts per million (ppm) and coupling constants $(J)$ in Hertz. Mass spectra were obtained on a Nermag R-10-10C spectrometer with chemical ionization $\left(\mathrm{NH}_{3}\right)$ 
and mode $\mathrm{m} / \mathrm{z}$ (amu) [\% relative base peak $(100 \%)]$. Semi-preparative HPLC was performed on a Waters Autopurification ZQ System equipped with a 2767 Sample Manager, a 2525 Binary Gradient Module and a 2996 Photodiode Array Detector, coupled to Waters Micromass ZQ analyzer. The HPLC purifications were performed on XTerra Prep RP C18 $(19 \times 150 \mathrm{~mm})$ columns, using reverse-phase conditions ( 2 to $100 \%$ acetonitrile with $0.1 \%$ TFA over 20 min). MS: Nermag R-10-10C, chemical ionization (NH3) mode $\mathrm{m} / \mathrm{z}$ (amu) [\% relative base peak (100\%)].

\section{1,12-Didehydro-5,6-} dihydrodibenzo[a,e][8]annulen-5-yl 4-nitrophenyl Carbonate (2)

4-Nitrophenyl chloroformate $(0.9 \mathrm{~g}$, $4.6 \mathrm{mmol}, 2$ equiv. $)$ and pyridine $(0.9 \mathrm{~mL}$, $11.4,5$ equiv.) were added to a solution of 11,12-didehydro-5,6-dihydrodibenzo[a,e] [8]annulen-5-ol (1, $0.5 \mathrm{~g}, 3.6 \mathrm{mmol}, 1$ equiv.) in DCM $(68 \mathrm{~mL})$ and the reaction mixture was stirred for $8 \mathrm{~h}$ at $25^{\circ} \mathrm{C}$. The solution was washed with brine $(2 \times 23 \mathrm{~mL})$. The organic phase was dried with $\mathrm{MgSO}_{4}$ and concentrated under reduced pressure. The crude product was then purified by flash column chromatography (PE/DCM $2: 1)$ to give 2 as a white solid $(0.8 \mathrm{~g}, 88 \%)$. The analytical data were in accordance with the reported characterization. ${ }^{[13]}$

\section{Preparation of Ligand 4}

11,12-Didehydro-5,6-dihydrodibenzo[a,e][8]annulen-5-yl 4-nitrophenyl carbonate (2, $0.67 \mathrm{~g}, 1.7 \mathrm{mmol}, 1$ equiv.) was added to a solution of $N-(2-\{2-[2-$ (2- aminoethoxy)ethoxy]ethoxy $\}$ ethyl)5-[(4R)-2-oxohexahydro-1H-thieno[3,4d]imidazol-4-yl]pentanamide $(3,0.72 \mathrm{~g}$, $1.7 \mathrm{mmol}, 1$ equiv.) and triethylamine $(0.7$ $\mathrm{mL}, 5.2 \mathrm{mmol}, 3$ equiv.) in DMF (194 mL), under an argon atmosphere. The reaction mixture was stirred overnight at rt, concentrated under reduced pressure and the residue was purified by silica gel flash chromatography (DCM/MeOH 98:2) to afford 4 as a green solid (225 mg, $20 \%$ ). IR (film): $3330,2920,2865,1780,1705,1520,1450$, 1330, 1205, 1075, 955, 925, 860, 815, 760, $730,685,645,565,545,520,515 \mathrm{~cm}^{-1}$. ${ }^{1} \mathrm{H}-\mathrm{NMR}\left(400 \mathrm{MHz}, \mathrm{CDCl}_{3}\right): \delta=7.52(\mathrm{~d}$, $1 \mathrm{H}$, aromatic, ${ }^{2} J=7.6 \mathrm{~Hz}, \mathrm{CH}$ (aromatic)), 7.41-7.26 (m, 7H, $7 \mathrm{CH}$ (aromatics)), 5.50 $(\mathrm{s}, 1 \mathrm{H}, \mathrm{CH}), 4.47(\mathrm{~m}, 1 \mathrm{H}, \mathrm{CH}), 4.29(\mathrm{~m}$, $1 \mathrm{H}, \mathrm{CH}), 3.66-3.62\left(\mathrm{~m}, 8 \mathrm{H}, 4 \mathrm{CH}_{2}\right), 3.60-$ $3.53\left(\mathrm{~m}, 4 \mathrm{H}, 2 \mathrm{CH}_{2}\right), 3.47-3.36(\mathrm{~m}, 4 \mathrm{H}$, $\left.2 \mathrm{CH}_{2}\right), 3.19-3.09$ (m, 2H, $\left.2 \mathrm{CH}\right), 2.96-$ $2.86(\mathrm{~m}, 2 \mathrm{H}, 2 \mathrm{CH}), 2.71\left(\mathrm{~d}, 1 \mathrm{H},{ }^{2} \mathrm{~J}=12.6\right.$ $\mathrm{Hz}, \mathrm{CH}), 2.19\left(\mathrm{t}, 2 \mathrm{H},{ }^{2} \mathrm{~J}=7.7 \mathrm{~Hz}, \mathrm{CH}_{2}\right)$, 1.70-1.60 (m, 4H, 2 $\left.\mathrm{CH}_{2}\right), 1.45-1.40(\mathrm{~m}$,

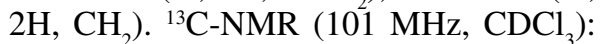
$\delta=172.8,130.0,128.1,127.1,126.1$, $123.8,70.4,70.1,61.9,60.3,55.4,46.2$, $40.5,39.2$, 29.7, 28.0, 25.6, 25.4. HRMS
(ESI): $(\mathrm{m} / \mathrm{z})$ : calcd for $\mathrm{C}_{35} \mathrm{H}_{4} \mathrm{~N}_{4} \mathrm{O}+\mathrm{H}$ : 665.3009, found: 665.3010. $[\alpha]_{\mathrm{D}}^{25}=0.1(\mathrm{c}$ $=0.1, \mathrm{DCM})$.

\section{5-[(6-Aminohexyl)carbamoyl]ben- zene-1,2,3-triyl Triacetate (7)}

Few drops of DMF were added to 3,4,5-triacetoxy benzoic acid (1 g, 3.4 mmol, 1 equiv. $)$ in dry DCM $(6 \mathrm{~mL})$. The reaction was cooled to $0{ }^{\circ} \mathrm{C}$ and oxalylchloride $(0.31 \mathrm{~mL}, 3.7 \mathrm{mmol}, 1.5$ equiv.) was added drop wise. After $15 \mathrm{~min}$ the reaction mixture was allowed to reach $\mathrm{rt}$ and stirred for $1 \mathrm{~h}$. The solution was concentrated under reduced pressure and the residue was suspended in dry DCM (4.5 $\mathrm{mL})$. A solution containing N-Boc-1,6hexadiamine $(0.72 \mathrm{~g}, 3.4 \mathrm{mmol}, 1$ equiv. $)$ and DIPEA (1.73 mL, $10.1 \mathrm{mmol}, 3$ equiv.) in DCM ( $4.5 \mathrm{~mL})$ was added drop wise at 0 ${ }^{\circ} \mathrm{C}$. After 15 min the reaction mixture was allowed to reach room temperature and stirred for $1 \mathrm{~h}$. The solution was concentrated under reduced pressure and the residue was purified by flash column chromatography (AcOEt/EP 1:1). The resulting product was dissolved in $4 \mathrm{M} \mathrm{HCl}$ in dioxane and stirred for $1 \mathrm{~h}$ at room temperature. $\mathrm{HCl}$ was coevaporated three times with diethyl ether to afford a white paste $(400 \mathrm{mg}, 30 \%$ for 2 steps). IR (film): 3265, 2935, 2860 , 2225,1770, 1635, 1585, 1550, 1490, 1435, $1370,1315,1180,1120,1050,1010,975$, 890, 870, 820, 760, 730, $700590 \mathrm{~cm}^{-1}$. ${ }^{1} \mathrm{H}$ NMR (400 MHz, MeOD): $\delta=7.64$ (s, $1 \mathrm{H}, \mathrm{CH}), 3.39\left(\mathrm{t}, 2 \mathrm{H}, \mathrm{CH}_{2}\right), 2.92(\mathrm{t}, 1 \mathrm{H}$, $\left.\mathrm{CH}_{2}\right), 2.30\left(\mathrm{~s}, 9 \mathrm{H}, 3 \mathrm{CH}_{3}\right), 1.66(\mathrm{~m}, 4 \mathrm{H}, 2$ $\left.\mathrm{CH}_{2}\right), 1.44\left(\mathrm{~m}, 4 \mathrm{H}, 2 \mathrm{CH}_{2}\right) \cdot{ }^{13} \mathrm{C}$ NMR (101 MHz, MeOD): $\delta=169.50,168.35,133.72$, $121.00,40.81,40.63,30.1,28.44,27.32$, 26.96, 20.38, 19.96. MS (ESI): HRMS (ESI): $(\mathrm{m} / \mathrm{z})$ : calcd for $\mathrm{C}_{19} \mathrm{H}_{26} \mathrm{~N}_{2} \mathrm{O}_{7}+\mathrm{H}$ : 395.1818, found: 395.1823 .

\section{1,12-Didehydro-5,6-dihydrodi- benzo[a,e][8]annulen-5-yl(6- \{[(3,4,5-trihydroxy phenyl)carbonyl] amino\}hexyl) Carbamate (8)}

5-[(6-aminohexyl)carbamoyl]benzene-1,2,3-triyl triacetate $(7,75 \mathrm{mg}, 0.2$ mmol, 1 equiv.) was dissolved in DMF (18 $\mathrm{mL})$ and carbonic acid, 5,6-dihydro-11,12didehydro-dibenzo $[a, \quad e]$ cycloocten-5-yl ester, 4-nitrophenyl ester (2,80 mg, 0.2 mmol, 1 equiv.), followed by triethylamine ( $0.08 \mathrm{~mL}, 0.6 \mathrm{mmol}, 3$ equiv.) were added. The reaction mixture was stirred overnight at room temperature. DMF was removed under reduced pressure and the product was purified by flash column chromatography (AcOEt/EP 1:1 then 2:1) (150 mg, $46 \%)$. The resulting intermediate $(33 \mathrm{mg}$, $0.05 \mathrm{mmol}, 1$ equiv.) was dissolved in THF at $0{ }^{\circ} \mathrm{C}$ and a $1 \mathrm{M}$ solution of $\mathrm{LiOH}(0.15$ $\mathrm{mL}, 0.15 \mathrm{mmol}, 3$ equiv.) was added. The reaction was monitored by MS until total conversion of the starting material. The product was purified by HPLC ((XTerra Prep RP C18, $(25 \times 150 \mathrm{~mm}$ Waters $))$ to give $\mathbf{8}$ (10 mg, 38\%). IR (film): 3275 , 2935, 1695, 2595, 1515, 1450, 1330, 1200, $1135,1035,865,755,720,645,585 \mathrm{~cm}^{-1}$. ${ }^{1} \mathrm{H}$ NMR (400 MHz, MeOD): $\delta=7.38(\mathrm{~d}$, $1 \mathrm{H}$, aromatic, $\mathrm{CH}), 7.37-7.29(\mathrm{~m}, 7 \mathrm{H}$, aromatics, $\left.(\mathrm{CH})_{7}\right), 6.82\left(\mathrm{~s}, 2 \mathrm{H},(\mathrm{CH})_{2}\right)$, $5.42\left(\mathrm{~m}, 1 \mathrm{H}, \mathrm{C}\left(1^{\prime}\right) \mathrm{H}\right), 3.22\left(\mathrm{dd}, 1 \mathrm{H},{ }^{2} \mathrm{~J}=\right.$ $\left.15.0{ }^{3} \mathrm{~J}=2.0 \mathrm{~Hz}, \mathrm{CH}_{2}\right), 3.11\left(\mathrm{t}, 2 \mathrm{H},{ }^{2} \mathrm{~J}=\right.$ $\left.2.0 \mathrm{~Hz}, \mathrm{CH}_{2}\right), 2.82\left(\mathrm{dd}, 1 \mathrm{H},{ }^{2} J=15.0{ }^{3} \mathrm{~J}=\right.$ $\left.3.8 \mathrm{~Hz}, \mathrm{CH}_{2}\right), 1.60-1.29$ (m, 10H, $5 \mathrm{CH}_{2}$ ). ${ }^{13} \mathrm{C}$ NMR (100 MHz, MeOD): $\delta=169.12$, $156.64,152.34,151.03,136.52,129.57$, $127.92,127.81,126.89,126.84), 125.74$ $125.48,124.99,123.47,112.39,109.57$, 76.40, 45.74, 40.28, 39.36, 29.40, 29.10, 26.25, 26.06. MS (ESI): HRMS (ESI): $(\mathrm{m} / \mathrm{z})$ : calcd for $\mathrm{C}_{30} \mathrm{H}_{30} \mathrm{~N}_{2} \mathrm{O}_{6}+\mathrm{H}$ : 515.2182 , found: 515.2180. $[\alpha]_{\mathrm{D}}^{25}=0.1(c=0.004$, $\mathrm{CH}_{2} \mathrm{Cl}_{2}$ ).

\section{Coating of HA and TCP Bioceramics}

$\operatorname{Discs}(\mathrm{d}=2.5 \mathrm{~cm}, \mathrm{~h}=0.5 \mathrm{~cm})$ of densely sintered HA and TCP biomaterials were incubated in a solution of $\mathbf{8}$ at increasing concentrations $(0,5$ and $10 \mu \mathrm{M})$ for $24 \mathrm{~h}$ at room temperature in the dark under slight stirring. The discs were washed three times with water and dried under vacuum for $24 \mathrm{~h}$.

\section{Cell Source and Culture Conditions}

Human fetal osteoblasts were derived by the explant technique from the femoral bone of a 12-week old fetus according to a protocol accepted by the Lausanne Hospital and University Ethics Committee and with the mother's oral and written approval (protocol No 51/01, 2008). These cells were used at passage 6 . Cells were routinely grown in DMEM medium containing $4.5 \mathrm{~g} / \mathrm{l}$ glucose, $10 \%$ fetal calf serum (FCS) and antibiotics (all from Invitrogen, Basel, Switzerland).

\section{Click Reaction on FsOs}

L-Azidohomoalanine (AHA) was purchased from Invitrogen, bovine serum albumin (BSA), from Sigma-Aldrich, Buchs, Switzerland. FsOs (80-90\% confluent) were washed with warm $\left(37{ }^{\circ} \mathrm{C}\right)$ PBS and incubated in methionine-free DMEM culture medium containing $4.5 \mathrm{~g} / \mathrm{L}$ glucose, antibiotics (P/S) and 3\% FCS for 30-60 min to deplete methionine reserves. Then they were incubated for $4 \mathrm{~h}$ in the presence of AHA $(50 \mu \mathrm{M})$ in fresh complete culture medium. The culture medium was removed and the cell layer was washed twice with PBS.

Stock solution of compound 4 (2.5 $\mathrm{mM}$ in PBS:DMF (7:3)) was prepared. For microscopy experiments, the click reaction was performed in a solution containing compound $4(20-100 \mu \mathrm{M})$ in DMEM 
containing additional HEPES $(20 \mu \mathrm{M})$. Incubation was performed for $1 \mathrm{~h}$ at $25^{\circ} \mathrm{C}$. The reaction mixture was removed and two washings with PBS at $37{ }^{\circ} \mathrm{C}$ allowed the complete removal of the reagents. The cells were then fixed using a $4 \%$ formaldehyde in PBS for $10 \mathrm{~min}$ at $25{ }^{\circ} \mathrm{C}$. After two washings with warm PBS, the cells were incubated with PBS containing 1\% BSA for $1 \mathrm{~h}$ at $25{ }^{\circ} \mathrm{C}$ and the labeling was performed. Streptavidin-Cy3 (SigmaAldrich) (1:100) and DAPI (4',6-diamidino-2-phenylindole, Roche Diagnostics) (1 $\mu \mathrm{g} / \mathrm{mL}$ in PBS) were then added and incubated with the cells for $30 \mathrm{~min}$ in the dark. After two washings with PBS during 5 min in the dark, the cells were fixed using a $4 \%$ formaldehyde solution in PBS at $4{ }^{\circ} \mathrm{C}$. Two additional washings with PBS were performed. The chamber was removed from the slide glass by using the chamber removal device and the evaluation of the click reaction was performed by fluorescence microscopy and slides photographed under a fluorescence microscope (Zeiss Axioplan 2).

\section{Cell Viability Assay}

Cell cultures were treated with compound $4(100 \mu \mathrm{M})$ in complete medium and additional HEPES $(20 \mu \mathrm{M})$ for $1 \mathrm{~h}$ at room temperature. Then cell survival was evaluated after $72 \mathrm{~h}$ to $144 \mathrm{~h}$ using the WST-1 assay. The culture medium was removed, cells were rinsed with DMEM without phenol red (Invitrogen) and incubated with the WST-1 reagent (Roche Diagnostics), diluted 1:10 in DMEM without phenol red for $3 \mathrm{~h}$. Optical density of the supernatants was measured at $450 \mathrm{~nm}$ in a multiwell-plate reader (iEMS Reader MF, Labsystems, Bioconcept) against a blank containing culture medium and WST-1.

\section{Click Reaction on the Biomaterial}

Petri dishes ( $9 \mathrm{~cm}$, Costar) were coated with $1000 \mu \mathrm{g} / \mathrm{mL}$ Rat Tail collagen I (Invitrogen) according to the supplier's protocol and human fetal osteoblasts were then grown in the dishes for $24 \mathrm{~h}$ until the cells are $80-90 \%$ confluent. The cells were washed with PBS and incubated in methionine-free DMEM culture medium (Invitrogen) for $60 \mathrm{~min}$ to deplete methionine reserves. Then the cells were incubated overnight in the presence of AHA (50 $\mu \mathrm{M}$ final concentration) in fresh complete methionine-free culture medium. The culture medium was removed and the cell layers were washed twice with PBS. Collagen coating was degraded by adding $0.1 \mathrm{mg} /$ $\mathrm{mL}$ collagenase (Sigma-Aldrich) in PBS at $37{ }^{\circ} \mathrm{C}$ for $45 \mathrm{~min}$. The osteoblasts were then counted. Three $\mathrm{mL}$ of the cell suspension $\left(10^{5}\right.$ cells $\left./ \mathrm{mL}\right)$ were added on unfunctionalized HA and TCP biomaterials or on $\mathrm{HA}$ and TCP biomaterials functionalized with ligand $\mathbf{8}$, in a 6 -well plate (Costar) and incubated for $1 \mathrm{~h}$ at room temperature under slight agitation. Then the discs were washed once with PBS, fixed in cold methanol $\left(-20^{\circ} \mathrm{C}\right)$ for $5 \mathrm{~min}$ and incubated in $5 \%$ BSA for $1 \mathrm{~h}$ at room temperature. Cells were stained for $5 \mathrm{~min}$ at room temperature with a solution containing $0.05 \%$ crystal violet (Sigma-Aldrich) and $1.5 \%$ glacial acetic acid in water. Cells were imaged by stereomicroscopy (MZ16 FA Leica/DFC 480 Leica, $0.63 \mathrm{X}$ and 1.6 X, zoom $72 \mathrm{X}$ ),
3 pictures for each treatment were taken and the cell number was evaluated using the IMAGE J software.

Received: February 25, 2013

[1] M. Bohner, Mater Today 2010, 13, 24

[2] A. Mahendra, A. Maclean, Injury, Int. Care Injured 2007, 38, 7.

[3] J. R. Porter, T. T. Ruckh, K. C. Popat, Biotechnol. Prog. 2009, 25, 1539.

[4] J. Hohlfeld, A. D. de Buys Roessingh, N. HirtBurri, P. Chaubert, S. Gerber, C. Scaletta, P. Hohlfeld, L. A. Applegate, Lancet 2005, 366, 840.

[5] M. O. Montjovent, C. Bocelli-Tyndall, C. Scaletta, A. Scherberich, S. Mark, I. Martin, L. A. Applegate, D. P. Pioletti, Tissue Engin. 2009, $15 A, 1523$.

[6] J. A. Prescher, C. R. Bertozzi, Nat. Chem. Biol. 2005, $1,13$.

[7] M. F. Debets, C. W. J. van der Doelen, F. P. J. T. Rutjes, F. L. van Delft, ChemBioChem 2010 , 11,1168 .

[8] R. J. Griffin, Prog. Med. Chem. 1994, 31, 121.

[9] M. Koehn, R. Breinbauer, Angew. Chem. Int. Ed. 2004, 43, 3106

[10] J. F. Lutz, Angew. Chem. Int. Ed. 2008, 47, 2182.

[11] F. Borcard, A. Godinat, D. Staedler, H. Comas Blanco, A.-L. Dumont, C. Chapuis-Bernasconi, C. Scaletta, L. A. Applegate, F. Krauss Juillerat, U. T. Gonzenbach, S. Gerber-Lemaire, L. Juillerat-Jeanneret, Bioconjugate Chem. 2011, 22, 1422.

[12] F. Krauss Juillerat, F. Borcard, D. Staedler, C. Scaletta, L. A. Applegate, H. Comas, L. J. Gauckler, S. Gerber-Lemaire, L. JuilleratJeanneret, U. T. Gonzenbach, Bioconjugate Chem. 2012, 23, 2278

[13] N. E. Mbua, J. Guo, M. A. Wolfert, R. Steet, G.-J. Boons, ChembioChem 2011, 12, 1912.

[14] H. Comas, V. Laporte, F. Borcard, P. Mieville, F. Krauss Juillerat, M. Caporini, U. T. Gonzenbach, L. Juillerat-Jeanneret, S. GerberLemaire, Appl. Mater. Interface 2012, 4, 573.

[15] F. Borcard, D. Staedler, H. Comas, F. KraussJuillerat, U. Gonzenbach, S. Gerber-Lemaire, L. Juillerat-Jeanneret, J. Med. Chem. 2012, 55, 7988. 